\title{
The Thing about Chemistry: Investigating the Fundamental Chemistry Skills of Biology Education Students at Bielefeld University
}

\author{
Claas Wegner, Rachel LeeAnn Bruneman*, Antonia Steffen \\ Department of Biology, Osthushenrich-Center for Giftedness Research, Bielefeld University, Bielefeld, Germany \\ *Corresponding Author: rachel.bruneman@uni-bielefeld.de
}

\section{ABSTRACT}

Although fundamental chemistry acts as a prerequisite for fully comprehending imperative aspects of biology, Bielefeld University is one of three universities in North Rhine-Westphalia, Germany that does not require majors or minors in biology education to complete classes in general chemistry, before fulfilling graduation requirements. A study was utilized to determine to what extent graduate students possess the chemistry skills essential for teaching the state-mandated biology curriculum. The assessed graduate students consisted of individuals with and without chemistry as their second elected subject. The chemistry skills of the individual graduate students were measured with a non-standardized knowledge test. The results of each test were computed using an evaluation form and specified point system. Results revealed that the majority of the graduate students without chemistry as their second elected subject possessed an insufficient (e.g., poor and failing) level of understanding for fundamental chemistry, characteristically essential for instructing biology lessons. The findings in this study and in previous research have established grounds for discussing potential methods of intervention and further investigation of this field, to better prepare biology education students for their teacher training and future careers.

KEY WORDS: biology education; biology teachers; chemistry skills; secondary school; knowledge test

\section{INTRODUCTION}

I

$f$ the fundaments of chemistry play a prominent role in the didactics of biology, why is it possible at select universities in North Rhine-Westphalia (NRW), Germany, to attain a degree in biology education before acquiring a basic understanding of chemistry (QUAL-LiS NRW, 2016; Lumer, 1996)? A recent study in Bielefeld, Germany analyzed to what extent graduate students pursuing a degree in biology education possessed the fundamental chemistry skills essential for their teacher training and careers as secondary school biology instructors. To become a secondary school teacher in Germany, individuals are required to obtain at least a master's degree in two elected subjects from a state-accredited university. After graduation, students must complete an 18-month teacher training (i.e., internship) followed by practical exams at a school of their choice, before obtaining the right to teach for the state.

To measure the students' understanding of chemistry, a knowledge test was constructed and conducted with graduate students during a preparatory teacher training seminar at Bielefeld University. The sample consisted of individuals with and without chemistry as their second elected subject. The score and grade of each knowledge test were calculated by an evaluation form and specified point system. The results of the study revealed that graduate students, pursing a degree in biology education, typically did not possess the chemistry knowledge needed to instruct the state-mandated secondary school biology curriculum adequately.

Alongside the contributing theoretical background and hypotheses, this article presents a detailed overview of the utilized methods and results of the study, as well as a concise discussion concerning the hypothesized outcomes, design of the experiment, future research, and potential methods of intervention.

\section{Theoretical Background}

Although physicists and chemists can do without biology, biologists cannot do without physics and chemistry. Those who not only want to describe biology but also [want to teach] it, must possess an understanding of physics and chemistry... (Vollmer, 1992, p. 146).

This quote symbolizes the difference between memorization (i.e., describing) and comprehension (i.e., understanding) in the context of teaching. Utilizing mathematics as an example, individuals would not be expected to comprehend multiplication and division fully without first gaining a basic understanding of addition and subtraction. If this example is applied metaphorically to the relationship between biology and chemistry, a teacher cannot possess a full understanding of biology without first comprehending the fundamental properties of chemistry. 
In previous research, Löwe (1990a, 1990b), Vollmer (1992), Lumer (1996), Hesse (1981, 2000), and Lumer and Hesse (1993, 1997a, 1997b, 1998, 2001) acknowledged the prominence of chemistry throughout biology curriculum and recognized that it is crucial for biology instructors to maintain an adequate understanding of chemistry. In Table 1, the corresponding aspects of biology and chemistry are brought into perspective by distinguishing between the NRW statemandated secondary school biology curriculum and the properties of chemistry that overlap with the respective biology subject matter. The applicable aspects of chemistry (i.e., listed in Table 1) represent - for comprehensive purposes — ideal prerequisites for biology instructors.

Despite the relationship between the two subjects, biology education students at several universities in NRW are not obligated to attend chemistry seminars or lectures before fulfilling graduation requirements. Table 2 outlines a synopsis of nine universities in NRW, which currently offer a degree in biology at the secondary school level, and include the respective mandated chemistry seminars or lectures for biology education students. Students pursuing a degree in biology education at Bielefeld University are required to attend biology seminars where components of the seminar(s) focus on the basics of chemistry necessary for understanding biological content (Bielefeld University, 2016). However, in contrast to most other universities in NRW, Bielefeld University does not require biology education students to attend seminars or lectures focused solely on chemistry.

The expectation that biology education students acquire a sufficient level of understanding for chemistry by incorporating aspects of chemistry into biology seminars or lectures is realistic; however, it remains questionable if it is an effective method. Although research in this context is limited, the combined efforts of Lumer and Hesse (1993, 1997a, 1997b, 1998, 2001) and Lumer (1996) provided theoretical and empirical structure for the hypotheses and utilized test instruments in the recently conducted study. The findings of Jutta Lumer and Manfred Hesse were results of a three-part empirical experiment, focusing on Part I: The chemistry skills of $1^{\text {st }}$-year (i.e., undergraduate) biology students (Lumer \& Hesse, 1993), Part II: The biology and chemistry terminology comprehension of pupils (i.e., school children) (Lumer \& Hesse, 1997a), and Part III: The presence of chemistry in a biology classroom, from the perspective of secondary school biology teachers (Lumer \& Hesse, 1997b). Despite contextual differences, Part I and Part III of the empirical experiment contributed valuable perspectives to the design of this study.

Part I entailed a randomized sample of freshmen from the University of Münster, pursuing a degree in biology $(\mathrm{N}=253)$. In this experiment, a knowledge test containing 16 tasks was conducted. The tasks addressed aspects of general chemistry and biochemical-physiological fields (Lumer, 1996). The sample differentiated between students that had attended general chemistry courses in secondary school and students that had not. Although the group of students that had attended general chemistry classes performed statistically better than the group of students that had not, the mean performance results of the knowledge test revealed that only $25-30 \%$ of the tasks were answered correctly (Lumer \& Hesse, 1993). The results of Part I lead to the conclusion that fundamental chemistry seminars and/or lectures are necessary for students pursuing a degree in biology education, as the knowledge of chemistry acquired in secondary school — if at all — is not sufficient for an ideal career as a biology teacher.

This conclusion was reinforced by the results from Part III, where secondary school biology teachers were surveyed about what role chemistry played (i.e., had played) in their academic and professional careers $(\mathrm{N}=83)$. The sample consisted of biology teachers with chemistry as their second subject $(n=33)$, while the remainder of the sample taught alternative subjects (e.g., English, physical education, and mathematics $)(n=50)$. In this phase of the experiment, various conclusions were drawn from the perspectives of the surveyed biology teachers. In one of the conclusions, Lumer (1996) disclosed that various biology teachers who did not also teach chemistry (i.e., attend chemistry seminars or lectures during their academic career) experienced uncertainties regarding aspects of chemistry in biology lessons (Lumer, 1996). Others invested considerable amounts of time after graduation to acquire an understanding of chemistry for their career as a biology teacher (Lumer, 1996).

While the causes remain diverse, Lumer and Hesse (1998) claimed that these occurrences stem consistently from an inadequacy of the biology education programs, where often minimal to no lectures or seminars in the field of basic chemistry are required. Furthermore, biology teachers with and without chemistry as their second subjects expressed in Part III that chemistry should not be excluded from biology lessons because an understanding of chemistry is essential for discussing various topics in biology (Lumer, 1996).

The theoretical background presented in this section not only empowered the concept to examine basic chemistry skills of biology education students and analyze on-going consequences for future biology teachers but it also provided a basis to discuss methods of intervention to optimize biology education for future students.

\section{Hypotheses}

Stemming from probability and prior empirical research, the hypotheses of the recent study - utilizing a knowledge test - were constructed from students' predicted performance results. The aim of each hypothesis was to analyze the trend of mean performance scores from biology education students based on the students' second elected subject. For this reason, the hypotheses distinguish between two groups of biology education students. The group type corresponds to the students' second elected subject, chemistry, or other. Students with chemistry as their second elected subject are recognized as one group, while students with alternative (i.e., all subjects aside from chemistry) second elected subjects are recognized 


\section{Table 1: Secondary school biology curriculum and applicable aspects of fundamental chemistry}

\begin{tabular}{|c|c|c|}
\hline Curriculum & Biology subject matter & Applicable aspects of chemistry \\
\hline \multirow[t]{16}{*}{ Cell biology } & Cell structure & \\
\hline & Carbohydrates & Definition of molecule/atoms \\
\hline & Lipids & Typical functional groups \\
\hline & Proteins & $\begin{array}{l}\text { Molecular structure of different } \\
\text { macromolecules }\end{array}$ \\
\hline & & Covalent bonds \\
\hline & & $\begin{array}{l}\text { Interactions (hydrogen bonds, ionic WW, } \\
\text { Van der Waals forces) }\end{array}$ \\
\hline & & Polarity and hydrophilicity \\
\hline & & Hydrocarbon chemistry \\
\hline & & Acids and bases \\
\hline & Biomembrane & \\
\hline & Diffusion and osmosis & Electrical and chemical gradients \\
\hline & Transport on membranes & Brown's molecular motion \\
\hline & & Chemical equilibrium \\
\hline & Cell duplication and DNA & \\
\hline & Structure of DNA & Properties and structure of nucleic acids \\
\hline & Semiconservative replication & Isotopes and radioactivity \\
\hline \multirow[t]{12}{*}{ Energy metabolism } & Enzymes & \\
\hline & Importance of biocatalysts & $\begin{array}{l}\text { Exergonic and endergonic chemical } \\
\text { reactions }\end{array}$ \\
\hline & Enzymes as special proteins & Activation energy \\
\hline & & Chemical equilibrium \\
\hline & & Reaction kinetics \\
\hline & Dissimilation & \\
\hline & Aerobic and anaerobic dissimilation & $\begin{array}{l}\text { Reduction, oxidation, redox systems, } \\
\text { redox potentials }\end{array}$ \\
\hline & Importance of NAD + and ATP & $\begin{array}{l}\text { Design and functional principle of NAD+ } \\
\text { and ATP }\end{array}$ \\
\hline & Principle of ATP synthesis & $\begin{array}{l}\text { Typical functional groups and their } \\
\text { chemistry }\end{array}$ \\
\hline & & Electrical and chemical gradients \\
\hline & & Chemical equilibrium \\
\hline & & Exergonic and endergonic reactions \\
\hline \multirow[t]{5}{*}{ Genetics } & Protein biosynthesis & \\
\hline & Molecular processes & $\begin{array}{l}\text { Properties/molecular structure of nucleic } \\
\text { acids and proteins }\end{array}$ \\
\hline & Molecular genetic methods & \\
\hline & PCR & Molecular structure of DNA \\
\hline & Gel electrophoresis & Different binding types in the DNA \\
\hline \multirow[t]{6}{*}{ Neurobiology } & Neural information processing & \\
\hline & Wiring of neurons & Electrical and chemical gradients \\
\hline & Calculation of potentials & $\begin{array}{l}\text { Chemical equilibrium and equilibrium } \\
\text { potentials }\end{array}$ \\
\hline & Principle synapse function & \\
\hline & Molecular processes at neuronal membranes & Definition of ions \\
\hline & Effects of exogenous substances on the body & Electric charge \\
\hline \multirow[t]{6}{*}{ Ecology } & Environmental factors & \\
\hline & $\begin{array}{l}\text { Photosynthesis: Photoreaction and synthesis } \\
\text { reaction }\end{array}$ & Light and dye chemistry \\
\hline & & $\begin{array}{l}\text { Reduction, oxidation, redox systems, } \\
\text { redox potentials }\end{array}$ \\
\hline & & $\begin{array}{l}\text { Structure and functional principle of } \\
\text { NADP+ and ATP }\end{array}$ \\
\hline & & Typical functional groups \\
\hline & & Electrical and chemical gradients \\
\hline
\end{tabular}


Table 1: Secondary school biology curriculum and applicable aspects of fundamental chemistry (Continued)

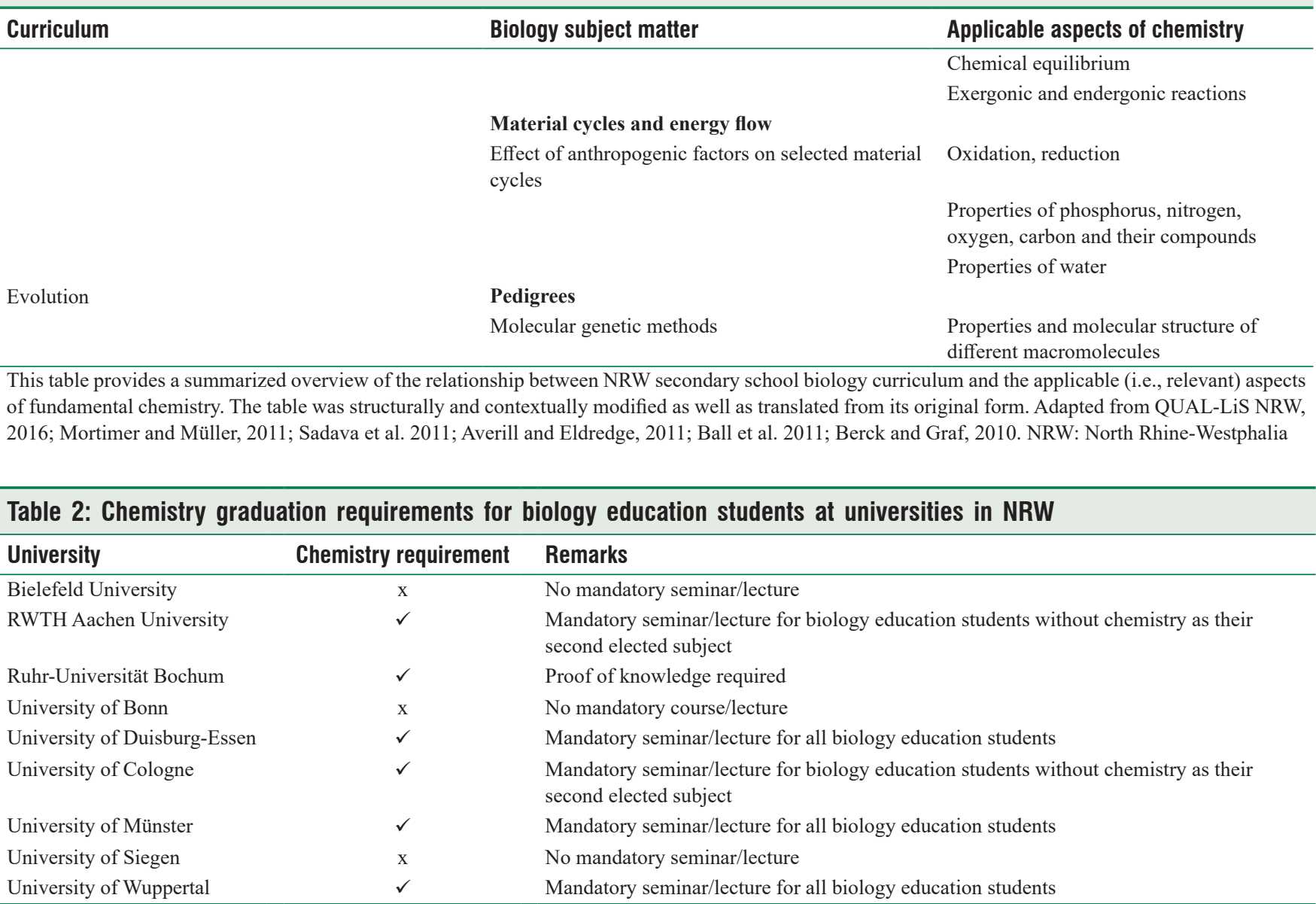

This table reflects nine universities in NRW and the respective graduation requirements concerning chemistry seminars and/or lectures for biology education students. $\checkmark$ Graduation requirement; xNo graduation requirement. Adapted from Bielefeld University, 2016; RWTH Aachen University, 2017; Ruhr-Universität Bochum, 2016; University of Bonn, 2017; University of Duisburg-Essen, 2017; University of Cologne, 2017; University of Münster, 2012; University of Siegen, 2016; University of Wuppertal, 2016. NRW: North Rhine-Westphalia

as a second group. The recent study was conducted based on the following two hypotheses:

Hypothesis 1: Biology education students with chemistry as their second elected subject will perform significantly better on the knowledge test than biology education students without chemistry as their second elected subject.

Hypothesis 2: Biology education students without chemistry as their second elected subject will score between 10 and 12 points (i.e., $25 \%$ and $30 \%$ of the maximal achievable score) on the knowledge test.

The first hypothesis, $\mathrm{H}_{1}$, represents the probable assumption that biology education students simultaneously pursuing a career in chemistry education will receive a better score on the knowledge test, due to their academic familiarity with chemistry, than biology education students simultaneously pursuing other subjects of education. As previously mentioned, Bielefeld University does not require biology education students to attend courses solely based on chemistry, unless that student has elected chemistry as their second subject (Bielefeld University, 2016).
The second hypothesis, $\mathrm{H}_{2}$, reflects the performance score prediction for biology education students, based on Part I of the empirical experiment from Lumer and Hesse (1993). The results of the experiment from Lumer and Hesse (1993) revealed that knowledge test performance scores for $1^{\text {st }}$-year biology students varied between $25 \%$ and $30 \%$ of the maximal achievable score. In the conducted study, it was assumed that the graduate students without chemistry as their second elected subject would resemble the performances of $1^{\text {st }}$-year biology students, due to the lack of furthered education (e.g., required chemistry seminars and/or lectures) in the subject of chemistry.

\section{METHODS}

The recent study, utilizing a knowledge test, was conducted in the winter semester of 2017-2018 and summer semester of 2018, during two preparatory teacher training seminars for biology education graduate students at Bielefeld University. The participants were a mixture of first- and second-semester biology graduate students, which promotes the assumption that both students with and without chemistry as their second elected subjects, obtained, respectively, similar amounts of 
education in the subject of chemistry. A total of 55 graduate students pursuing a master's degree in biology education, took part in the knowledge test. The size of the sample was equivalent to the number of students for approximately one graduating class. Although all participants represented graduates pursuing biology education, the second elected subjects of the students varied between physical education $(n=17)$, German $(n=11)$, chemistry $(n=11)$, mathematics $(n=9)$, social studies $(n=4)$, and English $(n=3)$. Written informed consent and verbal assent were obtained from all participants before testing. All procedures within the study were conducted in accordance with ethical policies of Bielefeld University's Ethics Committee.

To assess the understanding of chemistry, a non-standardized knowledge test was constructed to operationalize the fundamental chemistry skills of biology education students. The construction of the knowledge test was adapted from the method utilized in Part I of the Lumer and Hesse (1993) empirical experiment. The knowledge test consisted of 18 items, which addressed six different subject areas of chemistry. The subject areas were allocated into seven tasks, each task containing up to four subtasks (i.e., items). An overview of the knowledge test design is displayed in Table 3. The knowledge test was designed to not exceed a 30-min time period. For this reason, only selected subject matter from Table 1 was assessed.

After completing a list of demographic questions (e.g., gender, field of study, and second elected subject), each participant was provided verbal instructions and given $30 \mathrm{~min}$ to complete the knowledge test. To establish a realistic time-limit and ensure item comprehensibility, the knowledge test was - before the study - piloted with third-semester graduate students. The tasks in the knowledge test focused primarily on aspects of chemistry that is embedded in the biology curriculum, including but not limited to, general chemistry, inorganic chemistry, and biochemistry (Löwe, 1990a). With the intent to coincide with the NRW secondary school biology curriculum (Table 1), the items were structured to assess the comprehension of basic terminology, bonds and binding energy, polarity, acids and bases, concentration, as well as the description and application of oxidation and reduction. Three item examples are provided in the passage below:

\begin{tabular}{|c|c|c|}
\hline Task & Subtask (s) & Subject area \\
\hline 1 & 4 & Basic terminology \\
\hline 2 & 2 & Types of bonds and binding energy \\
\hline 3 & 3 & Polarity \\
\hline 4 & 2 & Acids and bases \\
\hline 5 & 2 & Concentration \\
\hline 6 & 4 & Oxidation and reduction (description) \\
\hline 7 & 1 & Oxidation and reduction (application) \\
\hline
\end{tabular}

The knowledge test contained a total of 18 subtasks (i.e., items), which addressed six subject areas over the course of seven tasks
Item 5: The following figure displays a section of a protein, in which different bonds between amino acid side chains can be seen. Please label the bonds with the provided "Technical Terms" [Ionic Interaction, Covalent Bond, Hydrogen Bond, Van der Walls Forces] by placing the corresponding letters $[A, B, C, D]$ in the respective boxes... (Task 2, Item 5, Translated Version)

Item 10: Decide which of the six statements [e.g., a/an (blank space) increases the $\mathrm{pH}$-level of a solution] apply to an acid and which to a base. To do this, please label the blank spaces with either "acid" or "base"... (Task 4, Item 10, Translated Version)

Item 12: In an experiment, caustic soda with a concentration of $2 \mathrm{~mol} / \mathrm{L}$ is required to calculate the $\mathrm{pH}$-dependence of enzyme-catalyzed reactions. A total of $250 \mathrm{~mL}$ is needed. Sodium hydroxide $(\mathrm{NaOH})$ is provided as a solid. Place a checkmark on the correct boxes to indicate which information you need for the calculation... (Task 5, Item 12, Translated Version)

In the first example, Item 5, participants were expected to match four terms (e.g., ionic interaction, covalent bond, hydrogen bond, and Van der Waals forces) to the respective molecular structure of amino acid. This example emphasizes the relationship between biology and chemistry because, without an understanding of these types of bonds, it is not plausible to understand the cell structure of proteins fully (Ball et al., 2011).

The second example, Item 10 , required participants to distinguish between acids and bases, according to a given statement. In the context of biology, understanding the concepts of acids and bases are important for the comprehension of metabolic processes, as well as for the understanding of environmental influences on complex ecosystems (Mortimer and Müller, 2011).

In the last example, Item 12, participants were provided with details of an experiment and asked to designate what further information is required to calculate the amount of sodium hydroxide needed for $250 \mathrm{~mL}$ of caustic soda with a concentration of $2 \mathrm{~mol} / \mathrm{L}$. For the purpose of practical experiments in a biology classroom, an understanding of how to calculate and produce solutions according to a given concentration is essential (Bayrhuber, 1994).

An evaluation form, constructed based on Lienert and Raatz (1998), Mortimer and Müller (2011), Riedel and Janiak (2011), Sadava et al. (2011), Ball et al. (2011), and Berg et al. (2014) was used to assess, analyze and interpret the results of the knowledge tests. The evaluation form established a respective point system for each item, which enabled all knowledge tests to be judged equally and objectively. Points were awarded diligently based on the complexity of the required task, to reduce the influence of guessing probability in the overall results. For example, multiple-choice items answered correctly were awarded fewer points than items requiring the participants to provide a free text answer. The maximal 
number of achievable points was 40 , if all tasks (i.e., subtasks) were answered correctly. The total number of points awarded for each individual knowledge test represented the raw performance scores of the participants. For interpretation purposes, the raw performance scores (i.e., percentage of items answered correctly) were converted to school grades according to specifications of the Central Abitur in NRW (Schulministerium Nordrhein-Westfalen, 2017). The grades were assigned based on a 6-point scale: Very well (1), good (2), satisfactory (3), sufficient (4), poor (5), and insufficient (6). For ranking purposes, grades were rounded to the nearest whole number.

The constructed knowledge test utilized to evaluate the chemistry skills of the biology education students is characterized as a non-standardized test instrument. This method of research was chosen based on limit ability and adaptability. The limited amount of previous research concerning the chemistry skills of biology education students consequentially limited the ability to conduct a study with a solid theoretical background and sufficient quality test criteria. Other methods of research, such as test instruments utilized in previous experiments (e.g., Lumer, 1996), are seemingly outdated and therefore do not represent the most recent NRW secondary school biology curriculum.

Despite the lack of information concerning the reliability and validity of the constructed test instrument, objectivity was fulfilled in both the execution and evaluation of the knowledge test. In addition, item difficulty and selectivity were calculated for each item of the test. Two items (i.e., item 13 and item 18) revealed difficulty index discrepancies, whereas only one item (i.e., item 18) revealed a selectivity discrepancy. The values of these discrepancies are specified in Table 4. For the purpose of future research, a larger sample of students and item modification, according to the results of the difficulty index and selectivity values, would be beneficial.

\section{RESULTS}

As illustrated in Figure 1, biology education students with chemistry as their second elected subject $(\mathrm{M}=30.27$, standard deviation $[\mathrm{SD}]=4.1$ ) scored $47.83 \%$ higher on the knowledge test, than the students with other second elected subjects $(\mathrm{M}=11.14, \mathrm{SD}=6.40)$. A two-sided Mann-Whitney U-test determined that the difference in mean performance scores (i.e., between chemistry and other) was statistically significant at the specified 0.05 level, $\mathrm{p}=0.003$.

To distinguish between performance levels, each individual score was assigned a grade proportionate to the number of points accumulated in the knowledge test. The utilized grading scale coincided with mandated secondary school grading criteria, determined by the respective German state (i.e., NRW) (Schulministerium Nordrhein-Westfalen, 2017). The distribution of the individual grades as well as the substantial difference between students with and without chemistry as their second elected subject is depicted in Figure 2. It was computed that the scores of $64 \%$ of biology education students $(n=35)$ reflected grade levels of either poor $(n=21)$ or insufficient $(\mathrm{n}=14)$. Among the $27 \%$ of students, whose scores were equivalent to very well $(n=3)$, good $(n=5)$, and satisfactory ( $n$ $=7$ ), only four scores consisted of students without chemistry as their second elected subject. This concludes, as seen in Figure 2, that only students with chemistry as their second elected subject were able to perform strongly (e.g., very well and good) on the knowledge test.

\section{DISCUSSION}

Under the assumption that chemistry skills play a fundamental role in the understanding of biology subject matter, it does not seem plausible nor practical to exclude chemistry lectures and/ or seminars from the graduation requirements of individuals

\begin{tabular}{llcc}
\hline \multicolumn{4}{l}{ Table } \\
\hline 4: & Item difficulty and item selectivity \\
\hline Task & Item & Difficulty index & Selectivity \\
\hline 5 & Item 13 & 0.17 & - \\
7 & Item 18 & 0.12 & 0.14 \\
\hline Item difficulty for item 13 and item & 18. Item selectivity for item 18
\end{tabular}

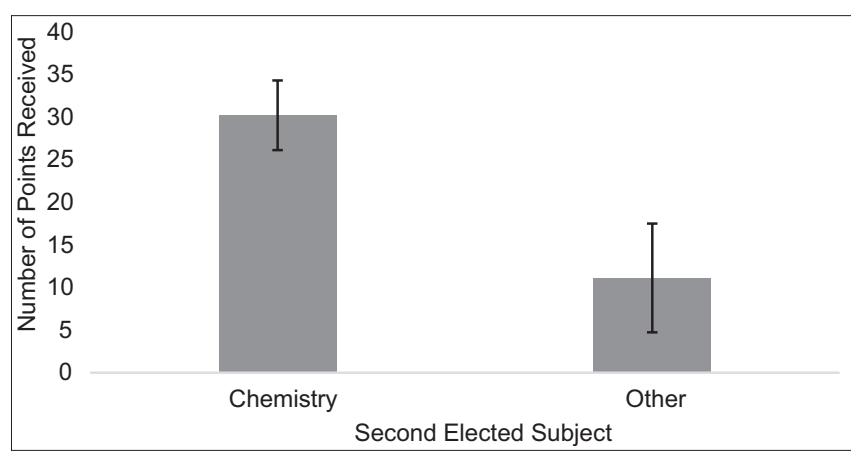

Figure 1: Mean performance scores of biology education students. This figure represents the mean performance scores achieved on the knowledge test by biology education students with $(n=11)$ and without chemistry $(n=44)$ as their second elected subject $(N=55)$

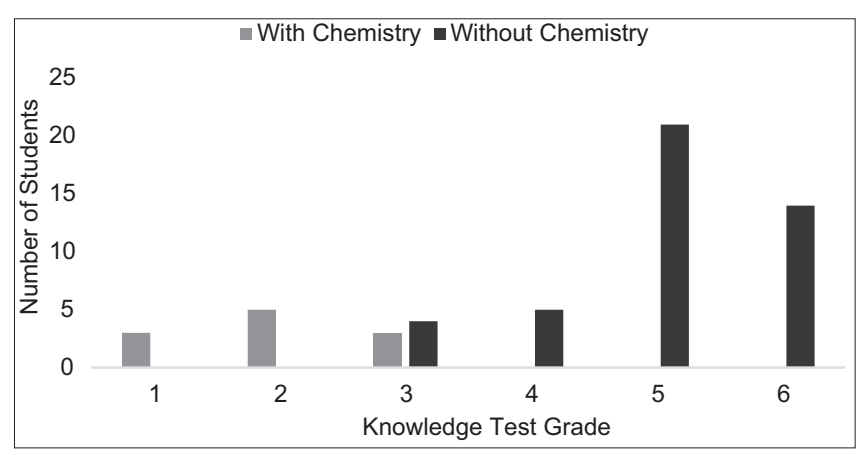

Figure 2: Knowledge test of biology education students. A graphical depiction of the grades (converted from the chemistry knowledge raw performance scores) received by the biology education students with $(n=11)$ and without chemistry $(n=44)$ as their second elected subject $(N=55)$. The following grades were received accordingly: $1(n=3), 2$ $(n=5), 3(n=7), 4(n=5), 5(n=21)$, and $6(n=14)$ 
pursuing a degree in biology education (Lumer \& Hesse, 1993, 1997a). Despite the rationality of this statement, selected universities in NRW have neglected to integrate mandatory chemistry lectures or seminars into their biology education programs. In this study, the focus resided on the chemistry skills of biology education students at Bielefeld University. The chemistry skills were measured with a non-standardized knowledge test and evaluated with a respective point system. An analysis of the constructed hypotheses revealed that the findings of this study concurred with multiple aspects of previous existing research.

Out of the two hypotheses (i.e., $\mathrm{H}_{1}$ and $\mathrm{H}_{2}$ ) constructed for this study, both were validated based on the results of the utilized test instrument. According to the validation of the first hypothesis, $\mathrm{H}_{1}$, biology education students with chemistry as their second elected subject performed significantly better on the knowledge test, than biology education students without chemistry as their second elected subject. Although the predictability of this outcome is far from complex, the statistically significant difference in mean performance scores was 19.13 points. This, in turn, equated not only to a significant difference in mean performance scores but also emphasized the fact that students without chemistry as their second elected subject performed roughly 3 times poorer on the knowledge test than students with chemistry as their second elected subject.

On the basis of the second verified hypothesis, $\mathrm{H}_{2}$, biology education students without chemistry as their second elected subject scored between 10 and 12 points (i.e., $25-30 \%$ of the maximum achievable score) on the knowledge test. The mean performance score of biology education students without chemistry as their second elected subject was $11.14(\mathrm{SD}=6.40)$, which is equivalent to $27.85 \%$ of the maximum achievable score. In reference to research from Lumer and Hesse (1996), the low scores of biology education students without chemistry as their second elected subject could be attributed to the fact that students had not received education in the subject of chemistry since secondary school. Consequentially, this means that the biology education students' understanding of chemistry is insufficient for fully comprehending imperative aspects of biology and biological processes (Lumer, 1996). Although the context of chemistry in biology education programs requires further research, the findings in this study indicate the need for evaluation and intervention concerning the academic structure of Bielefeld University's biology education program. Ideally, the evaluation would address the potential inadequacies of the program, as well as future consequences (e.g., Lumer \& Hesse, 1998) associated with not requiring biology education students to attend fundamental chemistry lectures or seminars. As indicated by Lumer (1996), a plausible form of intervention could entail integrating a general chemistry module (e.g., lecture or seminar) into the undergraduate biology education program. A module of this type would enable emphasis to be placed on the essentiality of basic chemistry in the context of teaching biology while coinciding with the concept that biology is best taught by teacher, who possess an understanding of fundamental chemistry (Vollmer, 1992).

\section{REFERENCES}

Averill, B., \& Eldredge, P. (2011). General Chemistry: Principles, Patterns and Applications. Washington: Saylor Foundation.

Ball, D.W., Hill, J.W., \& Scott, R.J. (2011). The Basics of General, Organic, and Biological Chemistry. Boston, MA: Saylor Foundation.

Bayrhuber, H. (1994). Zur interdisziplinarität des Biologieunterrichts [The Interdisciplinarity of Biology Lessons]. In: Bayrhuber, H., (Ed.). Interdisziplinäre Themenbereiche und Projekte im Biologieunterricht [Interdisciplinary Topics and Projects in Biology Education]. Kiel: IPN. pp. 29-34.

Berck, K., \& Graf, D. (2010). Biologiedidaktik: Grundlagen und Methoden [Biology Didactics: Basics and Methods]. 4h $^{\text {th }}$ ed. Berlin: Springer.

Berg, J.M., Tymoczko, J.L., \& Stryer, L. (2014). Biochemie [Biochemistry]. $7^{\text {th }}$ ed. Berlin: Springer.

Bielefeld University. (2016). Fakultät für Biologie: Biologie: Kernfach (Gymnasium und Gesamtschule) [Faculty of Biology: Biology: Core Subject (Secondary School)]. Available from: https://www.ekvv.unibielefeld.de/sinfo/publ/variante/62556682?m. [Last retrieved on 2019 Nov 06].

Hesse, M. (1981). Wird das $\mathrm{CO}_{2}$ in der Photosynthese reduziert oder oxidiert? [Is $\mathrm{CO}_{2}$ reduced or oxidiert in Photosynthesis?] Praxis der Naturwissenschaften: Biologie in der Schule [Practice of Natural Sciences: Biology in School], 9, 268-276.

Hesse, M. (2000). Erinnerungen an die Schulzeit: Ein Rückblick auf den erlebten Biologieunterricht junger Erwachsener [Memories of School: A Retrospective Look at the Biology Lessons of Young Adults]. Zeitschrift für Didaktik der Naturwissenschaften [Journal for Didactics of Natural Sciences], 6, 187-201.

Lienert, G.A., \& Raatz, U. (1998). Testaufbau und Testanalyse [Test Construction and Test Analysis]. $6^{\text {th }}$ ed. Weinheim: Beltz.

Löwe, B. (1990a). Biologie und chemie: Zum verhältnis der beiden naturwissenschaften im unterricht [Biology and chemistry: The relationship of the two natural sciences in class]. Unterricht Biologie [Biology Class], 153, 4-14.

Löwe, B. (1990b). Was sollten schüler zum abitur über den citratzyklus wissen? [What should students know about the citrate cycle for the abitur] Unterricht Biologie [Biology Class], 153, 45-47.

Lumer, J. (1996). Chemie im Biologieunterricht der Sekundarstufe II [Chemistry in Secondary School Biology Class]. Empirische Untersuchungen mit Schülern, Studienanfängern und Lehrern [Empirical Investigations of School Children, University Freshmen and Teachers]. Münster: Schüling-Verlag.

Lumer, J., \& Hesse, M. (1993). Chemiekenntnisse von studienanfängern: Untersuchung zur stellung der chemie im biologieunterricht [Chemistry knowledge of university freshmen: Investigating the placement of chemistry in biology class]. Bericht des Institutes für Didaktik der Biologie der Westfälischen Wilhelms-Universität Münster [Report from the Center for Didactics of Biology at the University of Münster], 2, $77-90$

Lumer, J., \& Hesse, M. (1997a). Schülervorstellungen über den weg vom gen zum enzym: Teil 1: Empirische wissensdiagnose im hinblick auf die bedeutung chemischer grundkenntnisse [Student conceptions about the path from gene to enzyme: Part 1: Empirical diagnosis of knowledge on the meaning of fundamental chemistry]. Mathematischer und naturwissenschaftlicher Unterricht [Mathematics and Natural Sciences Class], 2, 100-107.

Lumer, J., \& Hesse, M. (1997b). Schülervorstellungen über den weg vom gen zum enzym: Teil 2: Rückschlüsse auf die bedeutung chemischer grundkenntnisse für den Lernprozeß [Student conceptions about the path from gene to enzyme: Part 2: Conclusions about the meaning of fundamental chemistry knowledge for the learning process]. Mathematischer und naturwissenschaftlicher Unterricht [Mathematics and Natural Sciences Class7, 3, 165-171.

Lumer, J., \& Hesse, M. (1998). Chemie im biologieunterricht: Ein diskussionsbeitrag [Chemistry in biology class: A contributing 
discussion]. Praxis der Naturwissenschaften: Biologie in der Schule [Practice of Natural Sciences: Biology in School], 2, 129-150.

Lumer, J., \& Hesse, M. (2001). Diskussion und kritik zu ,wider die chemisierung des biologieunterrichts!' von L. J. Langlet [Discussion and criticism of 'countering the chemization of biology class' from L. J. Langlet]. Mathematischer und naturwissenschaftlicher Unterricht [Mathematics and Natural Sciences Class], 6, 371-373.

Mortimer, C.E., \& Müller, U. (2011). Chemie [Chemistry]. $10^{\text {th }}$ ed. Stuttgart: Thieme.

Qualitäts-und Unterstützungs Agentur Landesinstitut für Schule (QUAL-LiS NRW) [Quality and Support Agency State Institute for Schools]. (2016). Schulentwicklung: Biologie: Kompetenzbereiche und Inhaltsfelder des Faches [School Development: Biology: Areas of Competence and Subject Content]. Available from: https://www.schulentwicklung.nrw. de/lehrplaene/lehrplannavigator-s-ii/gymnasiale-oberstufe/biologie/ biologie-klp/kompetenzen/index.html. [Last retrieved on 2019 Nov 06].

Riedel, E., \& Janiak, C. (2011). Anorganische Chemie [Inorganic Chemistry]. $8^{\text {th }}$ ed. Berlin: De Gruyter.

Ruhr-Universität Bochum. (2016). Kenntnisse in Chemie, Physik und Mathematik für den Zwei-Fach-Bachelor of Arts mit Lehramtsoption [Knowledge of Chemistry, Physics and Mathematics for a Dual Major Bachelor of Arts with Teaching Option]. Available from: http://www. biologie.ruhr-uni-bochum.de/studium/bm/bar/cpm.html.de. [Last retrieved on 2019 Nov 06].

RWTH Aachen University. (2017). Prüfungsordnungsbeschreibung Biologie im lehramtsbezogenen Bachelorstudiengang: GyGe [Description of Examination Regulations in the Biology Education Bachelor Degree Program: Secondary School]. Available from: https://www.campus. rwth- aachen.de /rwth/all/examRule.asp ?ggu id=0x7C9C3093C926 1D43 ACBC585805 221F49\& tguid $=0 x E B B 2 D 1 C 296$ 13C04FBF47F 82813B5A4E9. [Last retrie ved on 2019 Nov 06].

Sadava, D., Hillis, D.M., Heller, H.C., \& Berenbaum, M.R. (2011). Life: The Science of Biology. $9^{\text {th }}$ ed. Sunderland: Sinauer.

Schulministerium Nordrhein-Westfalen. (2017). Schema und Beispiele zur Notenbildung im Zentral Abitur [Schemes and Examples of Grade Calculation for the Central Abitur]. Available from: https://www. standardsicherung.schulministerium.nrw.de/cms/upload/abitur-gost/ verfuegungen/Anlage_4_Schema_und_Beispiele_zur_Notenbildung. pdf. [Last retrieved on 2018 Apr 15].

University of Bonn. (2017). Prüfungsordnung für die Bachelor und Masterstudiengänge der Lehrerbildung der Rheinischen Friedrich-
Wilhelms-Universität Bonn [Examination Regulations of Bachelor and Master Degree Programs for Teacher Training at the University of Bonn]. Available from: https://www.bonndoc.ulb.uni-bonn.de/ xmlui/bitstream/handle/20.500.11811/1026/Amtl.\%20Bek.\%201728. pdf? sequence $=1 \&$ isAllowed $=y$. [Last retrieved on 2019 Nov 06].

University of Cologne. (2017). Prüfungsordnung: Unterrichtsfach Biologie [Examination Regulations: Subject of Biology]. Available from: http://www.zfl.uni-koeln.de/sites/zfl/Zfl-Navi/Pruefungsordnungen/ Bachelor/2017/GyGe/2_BA_Biologie_GymGe.pdf. [Last retrieved on 2019 Nov 06]

University of Duisburg-Essen. (2017). Fachprüfungsordnung für das Studienfach Biologie im Bachelorstudiengang mit der Lehramtsoption Gymnasien und Gesamtschulen an der Universität Duisburg-Essen [Subject Examination Regulations at the University of Duisburg-Essen for the Subject of Biology in the Bachelor's Degree Education Program with the Option to Teach at Secondary Schools]. Available from: https:// www.uni-due.de/imperia/md/content/zentralverwaltung/bereinigte_ sammlung/8 5 26 ws16.pdf. [Last retrieved on 2019 Nov 06].

University of Münster. (2012). Prüfungsordnung für das Fach Biologie im Rahmen der Bachelorprüfung innerhalb des Zwei-Fach-Modells an der Westfälischen Wilhelms-Universität Münster [Examination Regulations for the Subject of Biology Within the Bachelor Dual-Subject-Model at the University of Münster]. Available from: https://www.unimuenster. de/imperia/md/content/wwu/ab_uni/ab2012/ausgabe31/beitrag_02.pdf. [Last retrieved on 2019 Nov 06].

University of Siegen. (2016). Modulhandbuch zum Studiengang: Bachelor of Science Lehramt Biologie für Gymnasium und Gesamtschule [Modul Manual for the Study Course: Bachelor of Science in the Education of Biology for Secondary Schools]. Available from: http://www.chemiebiologie.uni-siegen.de/biologie/lehre/docs_po16/mhb_ba_biologie_ gymge_2016.pdf. [Last retrieved on 2019 Nov 06].

University of Wuppertal. (2016). Module des Studienganges Biologie im kombinatorischen Studiengang Bachelor of Arts zur Prüfungsordnung vom 06.10.2016 [Modul for Biology Study Courses in Combination with Bachelor of Arts Examination Regulations from 10.06.2016]. Available from: https://www.zpa.uni-wuppertal.de/fileadmin/zpa/Studiengaenge/ Komb._BA/Biologie_KBA_2016_Modulhandbuch.pdf. [Last retrieved on 2019 Nov 06].

Vollmer, G. (1992). Die wissenschaft vom leben: Das bild der biologie in der öffentlichkeit [The science of life: The public image of biology]. Biologie in unserer Zeit [Biology of our Time], 3, 143-150. 